\title{
PENGARUH BEBAN KERJA TERHADAP KEPUASAN KERJA DENGAN BURNOUT SEBAGAI INTERVENING PADA KANTOR POS INDONESIA CABANG MAKASSAR
}

\author{
Dewi Sartika Dg. Malino ${ }^{1}$, Jusuf Radja ${ }^{2}$, Herman Sjahruddin ${ }^{3}$ \\ ${ }^{1.2 .3)}$ Fakultas Manajemen, STIEM BONGAYA, MAKASSAR \\ Penulis Korespondensi Sartika.dewi147@gmail.com
}

\begin{abstract}
Abstrak
Penelitian ini bertujuan untuk menguji: Pengaruh beban kerja terhadap Kepuasan kerja dengan Burnout sebagai variabel intervening.Pendekatan penelitian ini adalah kuantitatif. Populasi dalam penelitian ini adalah karyawan tetap yang berada di PT. Pos Indonesia cabang Makassar. Sampel penelitian ini sebanyak 84 karyawan dalam PT. Pos Indonesia cabang Makassar dengan menggunakan analisis jalur. Dari model analisis tersebut nilai dari variabel dependen diperoleh dari hasil kuesioner dan menggunakan skala likert. Hasil penelitian ini menunjukkan bahwa: bahwa model yang diteliti telah memenuhi uji kelayakan model. Dimana beban kerja yang munjukkan hasil positif dansignifikan terhadap burnout, beban kerja yang menunjukkan hasil positif dan signifikan terhadap kepuasan kerja , Burnout yang menunjukkan hasil positif dan signifikan terhadap Kepuasan kerja , dan Beban kerja berpengaruh positif signifikan terhadap kepuasan kerja melalui Burnout.
\end{abstract}

Kata Kunci: Beban Kerja , Kepuasan Kerja, Dan Burnout 


\section{PENDAHULUAN}

Pada era globalisasi saat ini, persaingan antar perusahaan baik itu perusahaan BUMN ataupun perusahaan swasta meningkat seiring dengan laju pertumbuhan ekonomi global. Perusahan berlomba-lomba mendapatkan keuntungan yang maksimal dengan penggunaan sumber daya seminimal mungkin. Perusahaan menuntut sumber daya manusia yang terlibat di dalamnya harus dapat bersaing, bertahan dan mampu memenangi persaingan. Sumber daya perusahaan ada bermacam-macam namun yang utama adalah sumber daya manusia di dalamnya. manusia selalu berperan aktif dan dominan dalam setiap kegiatan organisasi karena manusia menjadi perencana, pelaku dan penentu terwujudnya tujuan organisasi

Sumber daya manusia di perusahaan dikatakan yang utama sebab sumber daya manusia itu sendiri yang menentukan kemana arah dan tujuan dari perusahaan. Jadi untuk dapat mewujudkan tujuan dari perusahaan, maka perusahaan harus memiliki sumber daya manusia yang unggul.

Perusahaan biasanya menargetkan sesuatu yang harus dicapai dalam waktu tertentu kepada karyawannya. SDM yang tidak mempunyai kesanggupan menghadapi tuntutantuntutan globalisasi, cenderung menganggap pekerjaan sebagai beban. Mereka menjalani pekerjaan sebagai suatu keharusan dan tuntutan. Kondisi akhirnya adalah tidak dirasakan makna kerja, SDM yang menganggap pekerjaan sebagai beban dapat dikatakan sebagai SDM yang mempunyai etos kerja rendah (I Made Devan Ganapathi, 2016).

PT. POS INDONESIA (Persero) Cabang Makassar merupakan salah satu cabang PT. POS INDONESIA (Persero), yaitu perusahaan jasa milik pemerintah yang bergerak khusus untuk memberikan pelayanan kepada seluruh masyarakat terhadap pengiriman barang . Sebagai ujung tombak perusahaan, karyawan dituntut untuk bekerja dengan maksimal agar pelayanan prima dapat tercapai bagi masyarakat. Menyadari hal tersebut, maka PT. POS INDONESIA (Persero) Cabang Makassar dirasa perlu untuk memperhatikan kepuasan kerja karyawan, dan mengantisipasi adanya beban kerja serta menghindari burnout.

Burnout adalah hasil psikologis dan fisik yang parah tingkat berkepanjangan dan stres tinggi di tempat kerja. Ini biasanya terjadi di antara karyawan yang tidak mampu mengatasi tekanan pekerjaan yang luas yang menuntut energi, waktu, dan sumber daya, dan di antara karyawan yang bekerja membutuhkan berurusan dengan orang.Para peneliti telah menemukan bahwa Burnout membawa dampak yang sangat besar untuk organisasi dan individu karena dampak negatif terhadap kerja karyawan serta sikap dan mengarah ke perilaku yang tidak diinginkan, seperti keterlibatan kerja rendah, kinerja tugas berkurang, dan meningkatnya pergantian karyawan. Pada karyawan yang mengalami Burnout menjadi kurang energik dan kurang tertarik dalam pekerjaan mereka. Mereka akan mengalami kelelahan secara emosional, apatis, depresi, mudah tesinggung, dan bosan. Cenderung untuk menemukan kesalahan pada segala aspek lingkungan kerja mereka, termasuk rekan kerja, dan bereaksi negatif terhadap usulan orang lain (Schultz \& Schultz, 1994) dalam (Ranny Hadiyanti,2013)

Dari hasil survey pada penelitian terhadap 84 karyawan Kantos Pos Cabang Makassar mengenai gejala-gejala Burnout terdapat 55 karyawan yang menunjukkan gejalagejala munculnya Burnout dan ketidakpuasan kerja yang ditimbulkan dengan adanya beban kerja yang didapatkan dari pimpinan yang tidak sebanding dengan pemberian gaji Karyawan yang menyebabkan terjdinya pemutusan hubungan kerja.

\section{TINJAUAN PUSTAKA}

Ketatnya persaingan dalam dunia bisnis, menuntut peningkatan sumber daya manusia (SDM) perusahaan dari segi kualitas, karena di dalam pengelolaan perusahaan SDM berperan sangat penting. Tujuan suatu perusahaan akan tercapai apabila karyawan memperoleh kepuasan kerja sesuai dengan yang diharapkan. Gumilar (2007), dalam Mahendrawan (2015) menyatakan apabila seseorang menjadi karyawan dimana telah bergabung dalam suatu wadah yakni 
organisasi, tentunya ia akan membentuk suatu harapan kerja yang mana terdiri dari keinginan, hasrat, kebutuhan maupun pengalaman masa lalunya ke dalam organisasi atau peruashaan tempatnya bernaung kini. Harapan kerja tersebut nantinya akan terkait dengan kepuasan kerja seseorang tersebut dalam hal ini karyawan organisasi tersebut, dimana dari harapan yang muncul tersebut akan dibandingkan dengan imbalan dari pekerjaan yang membentuk suatu kesesuaian yakni kepuasan kerja (Umar, 2008) dalam Mahendrawan (2015)

Manajmen sumber daya Manusia, didefinisikan sebagai suatu strategi dalam menerapkan fungsifungsi manajemen yaitu planning, organizing, leading and controlling, dalam setiap aktifitas atau fungsi operasional sumber daya manusia mulai dari proses penarikan, seleksi, pelatihan dan pengembangan, penempatan yang meliputi promosi, demosi dan transfer, penilaian kinerja, pemberian kompensasi, hubungan industrial, hingga pemutusan hubungan kerja, yang ditujukan bagi peningkatan kontribusi produktif dari sumberdaya manusia organisasi terhadap pencapaian tujuan organisasi secara lebih efektif dan efisien (Herman Sofyandi, 2009).

Kepuasan Kerja, merupakan suatu rasa yang timbul dari dalam diri seseorang, dimana ia mengevaluasi karakteristik pekerjaan tersebut secara positif (Robins, 2008:107). Rivai (2009:856) menyatakan kepuasan kerja seperti luapan perasaan suka maupun tidak suka, puas maupun tidak puas seseorang terhadap pekerjaannya. Menurut Robins (2008:108) kepuasan kerja dapat diukur dari sifat kerja, pengawasan, bayaran saat ini, peluang promosi dan rekan-rekan kerja sementara. Selain itu Afrizal (2012) menunjukkan bahwa kompensasi merupakan faktor lain yang mempengaruhi kepuasan kerja dalam Mahendrawan(2015)

Beban kerja, merupakan sekumpulan atau sejumlah tugas - tugas yang diberikan oleh pimpinan kepada seorang karyawan yang harus diselesaikan oleh suatu unit organisasi atau pemegang jabatan dalam jangka waktu tertentu. Menganalisis beban kerja merupakan suatu proses dalam menentukan jumlah kerja sumber daya manusia yang bekerja, diguanakan dalam menyelesaikan suatu pekerjaan untuk kurun waktu tertentu, tidak hanya beban yang berkaitan dengan kualias dan kuantitas produk yang dihasilkan oleh masing-masing karyawan. Berikut beberapa pengertian beban kerja dari beberapa ahli: Pengertian beban kerja menurut Menpan (2018) yang dialih bahasakan oleh Luh Kadek Budi Martini adalah: "Beban kerja adalah seperangkat atau sejumlah kegiatan yang harus dilakukan diisi oleh unit atau pemegang organisasi posisi dalam jangka waktu tertentu". Sedangkan pendapat lain enurut Siswanto (2017:38) yang dialih bahasakan oleh Nova Ellyzar pengertian beban kerja adalah: "Beban kerja adalah sejumlah kegiatan yang harus diselesaikan oleh suatu unit sorganisasi atau pemegang jabatan secara sistematis dengan menggunakan teknis analisis jabatan, teknik analisis beban kerja, atau teknik manajemen lainnya dalam jangka waktu tertentu untuk mendapatkan informasi tentang efisiensi dan efektivitas kerja suatu unit organisasi." Sama hal nya pengertian beban kerja menurut Munandar (2014:20) adalah: "Beban kerja adalah tugastugas yang diberikan pada tenaga kerja atau karyawan untuk diselesaikan pada waktu tertentu dengan menggunakan keterampilan dan potensi dari tenaga kerja. Berdasarkan beberapa definisi tersebut dapat disimpulkan bahwa beban kerja adalah sesuatu yang muncu yang dikarenakan jumlah kegiatan atau tugas- 29 tugas yang harus diselesaikan oleh karyawan secara sistematis dengan menggunakan keterampilan yang harus diselesaikan berdasarkan waktu.

BURNOUT, Khairani \& Ifdil (2015: 210) mengemukakan bahwa burnout merupakan suatu kondisi dimana seseorang merasa lelah dan jenuh secara fisik maupun emosional karena intensitas pekerjaan yang terlalu keras namun kaku dan menuntut pencapaian hasil yang sesuai dengan harapan. Sependapat dengan Burke (dalam Satriyo \& Survival, 2014: 53) yang menyebutkan bahwa burnout adalah proses psikologis yang terjadi karena stres pekerjaan yang tidak terlepaskan sehingga menghasilkan kelelahan emosi, perubahan kepribadian, dan perasaan pencapaian yang menurun. Menurut Primita \& Wulandari (2014: 17) burnout adalah suatu 
keadaan yang dipenuhi oleh rasa lelah fisik, mental, maupun emosional serta rendahnya penghargaan diri sehingga mengakibatkan banyak energi dan tenaga terbuang sia-sia serta menurunnya motivasi pada diri individu.

\section{METODE PENELITIAN}

Populasi yang digunakan dalam penelitian ini adalah seluruh karyawan PT. POS INDONESIA PERSERO,cabang Makassar berjumlah 100 orang karyawan, penghitungan sampel sebanyak orang karyawan menggunakan Rumus slovin, dan taknik pengambilan sampel adalah proportionate random sampling. Variabel dalam penelitian ini adalah variabel Beban kerja (X) dengan indikator beban fisik, beban mental, dan beban waktu .Variabel burnout (Z) dengan indikator kelelahan, Sinis, serta rendahnya penghargaan terhadap diri sendiri. Variabel kepuasan kerja (Y) dengan indikator isi pekerjaan, organisasi dan manajemen ,gaji , kesempatan untuk maju, dan rekan kerja.

Metode pengambilan data yang digunakan dalam penelitian ini adalah metode observasi, kuesioner dan matode literatur. Teknik analisis data menggunakan metode analisis data deskriptif dan pendekatan kuantitatif. Penelitian kuantitatif adalah penelitian dengan metode statistik untuk menguji hipotesis. Penelitian deskriptif adalah suatu metode dalam meneliti status kelompok manusia, suatu objek, suatu set kondisi, suatu system pemikiran ataupun suatu kelas peristiwa pada masa yang akan datang, tujuannnya adalah untuk membuat deskripsi atau gambaran sistematis dan akurat mengenai fakta-fakta yang terjadi

Berdasarkan metode analisis tersebut, hipotesis (Ha) yang akan di uji yaitu :

H1: Ada pengaruh beban kerja terhadap burnout karyawan

H2: Ada pengaruh beban kerja terhadap kepuasan kerja karyawan

H3 : Ada pengaruh Burnout terhadap kepuasan kerja karyawan

H4: Ada pengaruh beban kerja terhadap kepuasan kerja Karyawan dengan burnout sebagai variabel intervening

\section{Tempat dan Waktu}

Penelitian ini akan di laksanakan pada PT. POS INDONESIA cabang Makassar. Sulawesi Selatan.Waktu penelitian berkisar 1 (satu) bulan.

\section{Populasi dan Sampel}

Populasi adalah wilayah generalisasi yang terdiri atas : obyek/subyek yang mempunyai kualitas dan karakteristik tertentu yang di tetapkan oleh peneliti untuk di pelajari dan kemudian di tarik kesimpulannya, Sugiyono (2017: 80). Dalam penelitian ini populasi yang di ambil adalah seluruh Karyawan PT. Pos Indonesia yang berjumlah 100 orang

Sampel, adalah bagian dari jumlah dan karakteristik yang di miliki oleh populasi tersebut, Sugiyono (2017: 81). Sampel yang di ambil adalah seluruh karyawan PT.Pos indonesia cabang makassar dengan menggunakan metode sampel di mana beberapa dari setiap anggota populasi di pilih menjadi sampel. Dari penelitian ini di ambil populasi berjumlah 84 pegawai sesuai dengan jumlah keseluruhan pegawai dengan metode sampel jenuh.

\section{HASIL DAN PEMBAHASAN}

Pengujian pertama yang dilakukan yaitu uji normalitas, dengan uji statistik nonparametrik Kolmogorov-Smirnov (K-S). Hasil pengujian ini adalah sebagai berikut:

\section{Tabel 1}

Uji Normalitas

One-Sample KolmogorovSmirnov Test

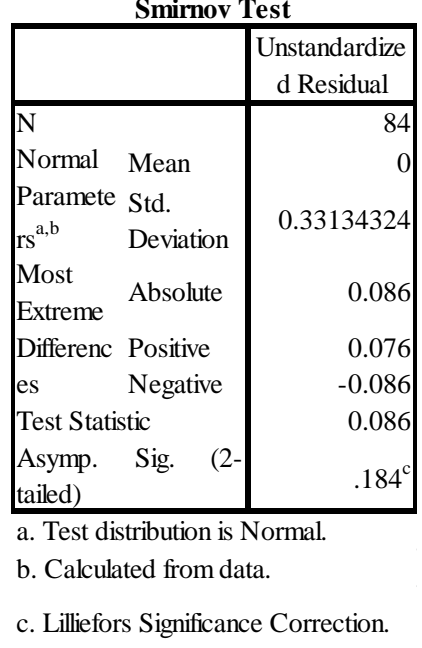

Berdasarkan tabel di atas, nilai asymp. Sig. (2tailed) yaitu 0.184. Nilai ini >0.05, apabila 
dibandingkan dengan kriteria yang ada, dan disimpulkan bahwa data dalam penelitian terdistribusi normal.

\section{Tabel 2}

\section{Uji Multikolinearitas}

\begin{tabular}{|c|c|c|c|}
\hline \multicolumn{4}{|c|}{ Coefficients $^{\text {a }}$} \\
\hline \multirow{2}{*}{ Model } & & \multicolumn{2}{|c|}{ Collinearity Statistics } \\
\hline & & Tolerance & VIF \\
\hline \multirow{3}{*}{1} & (Constant) & & \\
\hline & beban kerja & 0.348 & 2.872 \\
\hline & burnout & 0.348 & 2.872 \\
\hline
\end{tabular}

a. Dependent Variable: KEPUASAN

Berdasarkan tabel di atas terlihat bahwa nilai tolerance mendekati angka 1 dan nilai variance inflation factor (VIF) di sekitar angka 1 untuk setiap variabel, yang ditunjukkan dengan nilai tolerance untuk beban kerja 0.348 dan burn out 0.348 . Selain itu nilai VIF untuk beban kerja 2.872 dan burn out 2.872. Suatu model regresi dikatakan bebas dari problem multiko apabila memiliki nilai VIF kurang dari 10. Dengan demikian, dapat disimpulkan bahwa model persamaan regresi tidak terdapat problem multiko dan dapat digunakan dalam penelitian ini

Tabel 3

\section{Uji Heteroskedastisitas}

\begin{tabular}{|c|c|c|c|c|c|c|c|c|}
\hline \multicolumn{9}{|c|}{ Coefficients $^{\mathrm{a}}$} \\
\hline \multirow{2}{*}{ Model } & & \multicolumn{2}{|c|}{$\begin{array}{c}\text { Unstandardized } \\
\text { Coefficients } \\
\end{array}$} & \multirow{2}{*}{$\begin{array}{c}\begin{array}{c}\text { Standardized } \\
\text { Coefficients }\end{array} \\
\text { Beta }\end{array}$} & \multirow{2}{*}{$\mathrm{t}$} & \multirow{2}{*}{ Sig. } & \multicolumn{2}{|c|}{$\begin{array}{c}\text { Collinearity } \\
\text { Statistics } \\
\end{array}$} \\
\hline & & B & Std. Error & & & & $\begin{array}{c}\text { Toleranc } \\
\mathrm{e}\end{array}$ & VIF \\
\hline & (Constant) & -0.221 & 0.203 & & -1.091 & 0.279 & & \\
\hline 1 & $\begin{array}{l}\text { beban } \\
\text { kerja }\end{array}$ & -0.075 & 0.054 & -0.251 & -1.387 & 0.169 & 0.348 & 2.5 \\
\hline & burnout & 0.192 & 0.081 & 0.429 & 2.366 & 0.06 & 0.348 & 2.6 \\
\hline
\end{tabular}

Berdasarkan hasil pengujian uji heterokedastisitas pada table 4.8 menunjukkan bahwa independen yaitu BORG memiliki nilai signifikan $0.169>0.05$, variable pemoderasi yaitu KOMP memiliki nilai signifikan 0.060>0.05. Berdasarkan hasil tersebut maka dapat disimpulkan bahwa data dalam penelitian ini tidak terdapat nilai heterokedastisitas yang terlihat dari nilai signifikan $>0.05$
Tabel 4

Uji Statistik Dekskriptif

\begin{tabular}{|l|r|r|r|r|c|}
\hline \multicolumn{5}{|c|}{ Descriptive Statistics } \\
\hline & $\mathrm{N}$ & Minimum & Maximum & Mean & $\begin{array}{c}\text { Std. } \\
\text { Deviation }\end{array}$ \\
\hline beban kerja & 84 & 2.33 & 4.89 & 4.0321 & 0.68057 \\
Burnout & 84 & 2.8 & 4.73 & 4.086 & 0.45467 \\
kepuasan kerja & 84 & 2.44 & 5 & 3.968 & 0.56356 \\
Valid N (listwise) & 84 & & & & \\
\hline
\end{tabular}

Tabel diatas menunjukkan ada 84 sampel yang digunakan untuk variable beban kerja dengan nilai minimum 2.33 nilai maksimum sebesar 4.89, nilai rata-rata atau mean sebesar 4.0321 dan standard deviation sebesar 0.68057 , untuk variable burnout dengan nilai minimum 2.80 nilai maksimum sebesar 4.73 , nilai rata-rata atau mean sebesar 4.080 dan standard deviation sebesar 0.45467, dan untuk variable kepuasan kerja dengan nilai minimum 2.44 nilai maksimum sebesar 5.00, nilai rata-rata atau mean sebesar 3.9680 dan standard deviation sebesar 0.56356

\section{Tabel 5}

\section{UJI DETERMINASI}

\section{TABEL BEBAN KERJA TERHADAP BURNOUT}

\begin{tabular}{|r|r|r|r|r|}
\hline \multicolumn{6}{|c|}{ Model Summary $^{\mathbf{b}}$} \\
\hline Model & $\mathrm{R}$ & R Square & $\begin{array}{r}\text { Adjusted } \\
\text { R Square }\end{array}$ & $\begin{array}{c}\text { Std. Error } \\
\text { of the } \\
\text { Estimate }\end{array}$ \\
\hline 1 & $.807^{\mathrm{a}}$ & 0.652 & 0.648 & 0.26993 \\
\hline
\end{tabular}

a. Predictors: (Constant), beban kerja

b. Dependent Variable: burnout

Pada tabel ini terlihat bahwa $\mathrm{R}$ Square atau koefisien determinasi yaitu 0.652. Secara manual $\mathrm{R}$ Square dapat dihitung dengan mengubah matriks koefisien jalur $\mathrm{X}$ menjadi matriks baris lalu memperkalikannya dengan matriks kolom Y. Dari R Square tersebut dapat dihitung koefisien jalur variabel lain diluar model yaitu $\rho Y_{1 \varepsilon}$ dengan rumus :

$$
\rho Y 1 \varepsilon=\sqrt{1-0.652=0.5899}
$$


Tabel 6

TABEL BURNOUT DAN BEBAN KERJA TERHADAP KEPUASAN KERJA

\begin{tabular}{|r|r|r|r|r|}
\hline Model & \multicolumn{1}{|c|}{ Model Summary } \\
\hline & R Square & $\begin{array}{r}\text { Adjusted } \\
\text { R Square }\end{array}$ & $\begin{array}{c}\text { Std. Error } \\
\text { of the } \\
\text { Estimate }\end{array}$ \\
\hline 1 & $.809^{\mathrm{a}}$ & 0.654 & 0.646 & 0.33541 \\
\hline
\end{tabular}

a. Predictors: (Constant), burnout, beban kerja

b. Dependent Variable: kepuasan kerja

Pada tabel ini terlihat bahwa R Square atau koefisien determinasi yaitu 0.654 . Secara manual $\mathrm{R}$ Square dapat dihitung dengan mengubah matriks koefisien jalur $\mathrm{X}$ menjadi matriks baris lalu memperkalikannya dengan matriks kolom Y. Dari R Square tersebut dapat dihitung koefisien jalur variabel lain diluar model yaitu $\rho \mathrm{Y}_{1 \varepsilon}$ dengan rumus :

$$
\rho \mathrm{Y} 1 \varepsilon=\sqrt{1-0.654=0.5882}
$$

\section{Analisis Jalur (Path Analyse)}

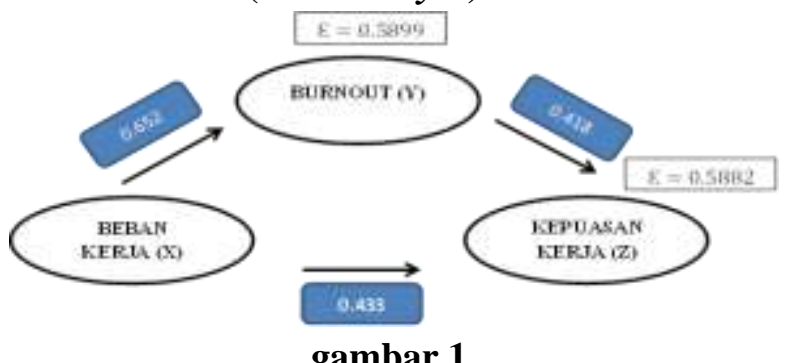

Diketahui pengaruh langsung yang diberikan beban kerja (X) terhadap kepuasan kerja (Z) sebesar 0.433, sedangkan pengaruh tidak langsung beban (X) kerja melalui komitmen organisasi ( $\mathrm{Y})$ terhadap kepuasan kerja $(\mathrm{Z})$ yaitu $0.652 \times 0.418=0.272$. maka pengaruh total yang diberikan beban kerja $(\mathrm{X})$ terhadap burnout $(\mathrm{Y})$ adalah pengaruh langsung ditambah dengan pengaruh tidak langsung yaitu: $0.433+0.272=$ 0.705. Maka dapat disimpulkan nilai pengaruh langsung beban kerja (X) 0.433 < nilai pengaruh tidak langsung terhadap turnover intention $(\mathrm{Z})$ melalui komitmen organisasi (Y) sebesar 0.705. hasil ini menunjukkan bahwa secara tidak langsung beban kerja $(\mathrm{X})$ berpengaruh signifikan terhadap kepuasan kerja (Z) melalui burn out (Y) Maka dapat disimpulkan sebagai berikut :

Analisis pengaruh $\mathbf{X}$ terhadap $\mathbf{Y}$ :dari analisis diatas diperoleh nilai signifikansi X sebesar 0,000 $<0,005$, sehingga dapat disimpulkan bahwa secara langsung terhadap pengaruh signifikansi $\mathrm{X}$ terhadap Y

Analisis pengaruh $\mathbf{X}$ terhadap $\mathbf{Z}$ : dari analisis diatas diperoleh nilai signifikansi $\mathrm{X}$ sebesar $0,000<0,005$, sehingga dapat disimpulkan bahwa secara langsung terhadap pengaruh signifikansi $\mathrm{X}$ terhadap Z

Analisis pengaruh $\mathbf{Y}$ terhadap $\mathbf{Z}$ : dari analisis diatas diperoleh nilai signifikansi $\mathrm{X}$ sebesar 0,000 $<0,005$, sehingga dapat disimpulkan bahwa secara langsung terhadap pengaruh signifikansi $Y$ terhadap Z

Analisis pengaruh $\mathrm{X}$ melalui $\mathrm{Y}$ terhadap $\mathrm{Z}$ : diketahui pengaruh langsung yang diberikan $X$ terhadap $Z$ sebesar 0,433. Sedangkan pengaruh tidak langsung $\mathrm{X}$ melalui $\mathrm{Y}$ terhadap $\mathrm{Z}$ adalah perkalian nilai beta $X$ terhadap $Y$ dengan nilai beta $\mathrm{Y}$ terhadap $\mathrm{Z}$ yaitu : 0.657 x $0.418=0.275$. maka pengaruh total yang diberikan beban kerja (X) terhadap burnout (Y) adalah pengaruh langsung ditambah dengan pengaruh tidak langsung yaitu: $0.433+0.272=0.705$.

\section{Tabel 7}

Uji Simultan (Uji F)

TABEL BEBAN KERJA TERHADAP BURNOUT

\begin{tabular}{|c|c|c|c|c|c|c|}
\hline \multicolumn{7}{|c|}{ ANOVA $^{a}$} \\
\hline Model & & $\begin{array}{l}\text { Sum of } \\
\text { Squares }\end{array}$ & df & Mean Square & F & Sig. \\
\hline \multirow{3}{*}{1} & Regression & 11.183 & 1 & \multirow{3}{*}{$\begin{array}{r}11.183 \\
0.073\end{array}$} & \multirow[t]{3}{*}{153.483} & \multirow[t]{3}{*}{$.000^{\mathrm{b}}$} \\
\hline & Residual & 5.975 & 82 & & & \\
\hline & Total & 17.158 & 83 & & & \\
\hline
\end{tabular}

b. Predictors: (Constant), beban kerja

Dari tabel diatas uji $\mathrm{F}$ dapat dirumuskan df1 = jumlah variabel (eksogen dan endogen) variabel bebas dan df2 = jumlah responden jumlah variabel (dependen dan independen). Jadi, df $1=3-1=2$ dan df $2=84-3=81$ atau yang disebut dengan nilai residual. Maka Ftabel diperoleh pada lampiran yaitu 3.11.

Tabel ini menunjukkan bahwa hasil uji $\mathrm{F}$ yaitu fhitung>ftabel (153.483 >3.11) dan nilai signifkan sebesar 0,000 . Hal berarti variabel endogen, yaitu beban keja secara simultan memiliki pengaruh terhadap burn out. 
Tabel 8

TABEL BURNOUT DAN BEBAN KERJA TERHADAP KEPUASAN KERJA

\begin{tabular}{|rl|r|r|r|c|c|}
\hline \multicolumn{1}{|l|}{ Model } & & $\begin{array}{r}\text { Sum of } \\
\text { Squares }\end{array}$ & df & Mean Square & F & Sig. \\
\hline \multirow{4}{*}{1} & Regression & 17.248 & 2 & 8.624 & 76.659 & $.000^{\mathrm{b}}$ \\
& $\begin{array}{r}\text { Residual } \\
\text { Total }\end{array}$ & 9.112 & 81 & 0.112 & & \\
\hline
\end{tabular}

a. Dependent Variable: kepuasan kerja

b. Predictors: (Constant), burnout, beban kerja

Tabel ini menunjukkan bahwa hasil uji $\mathrm{F}$ yaitu fhitung>ftabel $(76.659>3.11)$ dan nilai signifkan sebesar 0,000. Hal berarti seluruh variabel endogen, yaitu Burnout dan beban kerja secara simultan memiliki pengaruh terhadap kepuasan kerja

\section{Uji Parsial (Uji T)}

Uji $t$ digunakan untuk mengetahui seberapa jauh pengaruh satu variabel penjelas secara individual dalam menerangkan variasi variabel terikat.Pengujian melauli uji $\mathrm{t}$ adalah dengan thitung dan ttabel pada derajat signifikasi $95 \%(\alpha=0,05)$ dengan pengujian dua sisi.

Tabel 9

TABEL BEBAN KERJA TERHADAP BURNOUT

\begin{tabular}{|c|c|c|c|c|c|c|c|}
\hline \multirow{2}{*}{ Model } & \multicolumn{2}{|c|}{$\begin{array}{l}\text { Unstandardized } \\
\text { Coefficients }\end{array}$} & \multirow{2}{*}{$\begin{array}{c}\begin{array}{c}\text { Standardized } \\
\text { Coefficients }\end{array} \\
\text { Beta }\end{array}$} & \multirow{2}{*}{$\mathrm{t}$} & \multirow{2}{*}{ Sig. } & \multicolumn{2}{|c|}{$\begin{array}{l}\text { Collinearity } \\
\text { Statistics }\end{array}$} \\
\hline & B & $\begin{array}{c}\text { Std. } \\
\text { Error } \\
\end{array}$ & & & & \begin{tabular}{|c|}
$\begin{array}{c}\text { Toleranc } \\
\mathrm{e}\end{array}$ \\
\end{tabular} & VIF \\
\hline (Constant) & 1.911 & 0.178 & & 10.737 & 0 & & \\
\hline beban kerja & 0.539 & 0.044 & 0.807 & 12.389 & 0 & 1 & 1 \\
\hline
\end{tabular}

Berdasarkan hasil uji coefficient di atas memberikan bukti bahwa nilai koefisien regresi variabel beban kerja dengan nilai signifikan $0,000<0,05$ dan nilai $\mathrm{T}_{\text {hitung }} 12.389>\mathrm{t}_{\text {tabel }} 1.9897$. Sehingga dapat disimpulkan beban kerja mempunyai pengaruh signifikan terhadap burn out

\section{Tabel 10}

TABEL BURNOUT DAN BEBAN KERJA TERHADAP KEPUASAN KERJA

\begin{tabular}{|c|c|c|c|c|c|c|c|c|}
\hline \multirow[t]{2}{*}{ Model } & & \multicolumn{2}{|c|}{$\begin{array}{c}\text { Unstandardized } \\
\text { Coefficients } \\
\end{array}$} & \multirow{2}{*}{$\begin{array}{c}\begin{array}{c}\text { Standardized } \\
\text { Coefficients }\end{array} \\
\text { Beta }\end{array}$} & \multirow[t]{2}{*}{$\mathrm{T}$} & \multirow[t]{2}{*}{ Sig. } & \multicolumn{2}{|c|}{$\begin{array}{l}\text { Collinearity } \\
\text { Statistics }\end{array}$} \\
\hline & & B & Std. Error & & & & & $\mathrm{VIF}$ \\
\hline \multirow{3}{*}{1} & (Constant) & 0.406 & 0.343 & & 1.183 & 0.24 & & \\
\hline & $\begin{array}{l}\text { beban } \\
\text { kerja }\end{array}$ & 0.359 & 0.092 & 0.433 & 3.912 & 0 & 0.348 & \begin{tabular}{|l|}
2.9 \\
\end{tabular} \\
\hline & burnout & 0.518 & 0.137 & 0.418 & 3.774 & 0 & 0.348 & 2.9 \\
\hline
\end{tabular}
dilihat yaitu pada nilai $\mathrm{t}$ dengan nilai $\mathrm{df}=\mathrm{n}-\mathrm{k}-1=$
84-2-1 = 81. Pada tabel diatas menunjukkan hasil bahwa variabel beban kerjadengan nilai thitung lebih besar dari ttabel(3.912 < 1.9897) dan tingkat signifikan lebih kecil dari $0.05(0.000$ $<0.05$ ), Sedangkan variabel burnout dengan nilai thitung lebih besar dari ttabel(3.774 > 1.9897) dan nilai signifikan lebih kecil dari $0.05(0.000<$ 0.05), maka dapat disimpulkan bahwa $\mathrm{H}_{1}$ diterima yang berarti beban kerja dan burnout berpegaruh signifikan secara parsial terhadap kepuasan kerja.

Hasil penelitian ini sejalan dengan penelitian yang dilakukan oleh (Kusuma Ningrum,2016) Bahwa secara parsial pengaruh beban kerja berpengaruh terhadap burnout.

\section{KESIMPULAN}

Berdasarkan hasil penelitian, dapat disimpulkan bahwa beban kerja membuktikan bahwa variabel independen, yaitu burn out berpengaruh positif dan signifikan terhadap beban kerja kerja karyawan pada PT. Pos Indonesia cabang Makassar maka dinyatakan hipotesis pertama diterima. Berdasarkan hasil beban kerja membuktikan bahwa variabel independen, yaitu kepuasan kerja berpengaruh positif dan signifikan terhadap kepuasan kerja karyawan pada PT. Pos Indonesia cabang Makassar maka dinyatakan hipotesis kedua ditolak. Berdasarkan hasil burnout membuktikan bahwa variabel independen, yaitu kepuasan kerja berpengaruh positif dan signifikan terhadap komitmen organisasi pada PT. Pos Indonesia cabang Makassar maka dinyatakan hipotesis kedua ditolak. Berdasarkan hasil penelitian membuktikan bahwa Pengaruh beban kerja terhadap kepuasan kerja dengan burnout sebagai intervening berpengaruh positif dan signifikan terhadap PT. Pos Indonesia cabang Makassar maka dinyatakan hipotesis kedua diterima.

\section{REFERENSI}

Dea Multi Maharani.(2019). hubungan dantara self-eestem dengan academic burnout pada siswa kelas XI SMA Negeri I Semarang tahun ajaran 2018/2019

I Gede Mahendrawan,Ayu Desi Indrawati. (2015). PENGARUH BEBAN KERJA 
DAN KOMPENSASI TERHADAP KEPUASAN KERJA PT. PANCA DEWATA DENPASAR, Bali, Indonesia

I Made Devan Ganapathi. (2016). pengaruh work-life balance terhadap kepuasan kerja karyawan (studi pada PT. bio farma persero), $I V(1), 125-135$.

Kusumaningrum, I. Y. (2016). TERHADAP KINERJA PERAWAT MELALUI BURNOUT SEBAGAI VARIABEL INTERVENING PADA PT. NUSANTARA MEDIKA UTAMA RUMAH SAKIT PERKEBUNAN ( JEMBER KLINIK ), 10(3), 329-342.

Melati, P., Yo, P., Bagus, I., \& Surya, K. (2015). Putu Melati Purbaningrat Yo 1 Fakultas Ekonomi Universitas Udayana ( Unud ), Bali , Indonesia, 4(5), 1149-1165.

Suana, I. W. (2019). PENGARUH BEBAN KERJA TERHADAP BURNOUT DENGAN ROLE STRESS SEBAGAI VARIABEL MEDIASI PADA KARYAWAN RUMOURS RESTAURANT I Gede Indra Wira Atmaja 1 Fakultas Ekonomi dan Bisnis Universitas Udayana, Bali , Indonesia 